\title{
Control of urban parking based on zoning rates in the context of sustainable transportation
}

\author{
Ismiyati Ismiyati $1^{1, *}$, Yohannes Inigo Wicaksono ${ }^{1}$, Bambang Riyanto ${ }^{1}$, Mochamad Iqbal \\ Rajani $^{1}$, and Rizki Parulian ${ }^{1}$ \\ ${ }^{1}$ Department of Civil Engineering of Diponegoro University, Semarang, Indonesia
}

\begin{abstract}
Urban parking is a major challenge in several developing countries such as Indonesia. Dense traffic conditions are exacerbated by the lack of availability of off-street parking in public spaces, forcing vehicles to use on-street parking, which in turn impedes traffic flow and causes gridlock and traffic jams. Semarang City is a good case-study area, with significant parking problems which are clearly unresolved. The research objective is to develop urban parking controls by conducting a comprehensive parking rate analysis based on zoning, using the Analytic Hierarchy Process (AHP) model to direct and refine the research in a methodical way. The research results determined appropriate urban parking rates based not simply on zoning, but also accounting for the influence of additional quantifiable criteria: assessed land value, location and accessibility, additional value derived from various types of land use, economic capability/ability to pay, and hidden value ascribed to amenities/type of facilities. The highest weighted value, 8,498, was obtained for zone $\mathrm{A}$, which represents the trade zone (BWK 1/Urban Boundaries 1); the value obtained for zone $\mathrm{B}, 3,71$, represents the industrial zone (BWK 4/Urban Boundaries 4); and zone C (BWK 6/Urban Boundaries 6) is represented with the weighted value of 1,867 .
\end{abstract}

\section{Background of study}

Parking is a significant urban transportation problem, especially in developing countries such as Indonesia, according to [7,11]. These transportation problems in a developing country are a result of inefficient traffic patterns and lack of mobility caused by the increased use of private vehicles. The city of Semarang, chosen as the study area, had a clearly-unsolved parking problem, even though "andalalin" (traffic impact analysis) has been required from all developers as they plan to build units including housing, department stores, hotels, restaurants, hospitals, and tourist destinations. Semarang, which is the capital city of the province of Central Java, has attracted a population surge of upscale residents because of its high social development standards. This population growth has been followed by urban infrastructure development such as shopping centers, five-star hotels, recreation areas, offices, and housing units [14]. The transportation pressures generated by these social trends, as well as the upward mobility which promotes travelling to the places

*Corresponding author: ismiyati_hs@yahoo.com 
mentioned above, are escalating; it therefore becomes apparent that if these destinations do not also develop adequate roadways including parking facilities and parking controls, eventually the quality and quantity of travel will decrease, since the unavailability of parking areas will put extra stress and pressure on drivers and they will avoid returning.

In his paper, [8] explains there are several ways to define and create effective parking zones. One method is to classify by land use, differentiating between building types. Areas which consist of commercial buildings such as hotels, stores, theaters and offices will be placed in one zone, and residential areas will be placed in a different zone. Almost all parking and zoning rules currently use this method as a base reference.

In Indonesia, very few cities regulate parking zoning at this point in time, although there are many cities and urban centers that are large and densely populated enough to benefit from such regulation. The only city in Indonesia which enforces such zoning is Jakarta, although its zoning category is still classified as special zoning which is regulated in high traffic areas only. A parking study based on zoning was performed in Solo [1,3], which used a Revenue Model for the Zoning System (Revenue), involving the use of a classification system for on-street parking according to zone [12, 13, 14], specifically divided into 5 different parking zones which in implementation resulted in five-tiered parking rates $[3,18]$.

The difference in the scope and detail of the research presented in this paper is the specific objective: to be able to determine equitable parking rates for off-street parking by considering the related buildings as well as the overall zoning system, using the method of Process Hierarchy Analysis (AHP) [10,17]. Hierarchy Process is a model that is very flexible and gives an opportunity to a person or group to build on ideas and define a problem by making qualified assumptions to assign priority values, thereby finding consensus-based solutions [17], in this case, to establish a graduated series of parking rates for different zones based on the influence of multiple variables. Several significant variables such as land value, land use, economic factors, accessibility and facility were considered. A number of factors which are included in the land value, or NJOP (Nilai Jual Objek Pajak / Selling Value of Tax Object), of each different area will also affect these parking rates. Expanded parking capacity will help alleviate traffic flow problems as well as generate increased revenue, but implementation costs will be higher and these costs should also be considered when the parking rates are set. Another factor influencing parking rates is land use; if a certain zone has many shopping centers such as stores or tourist attractions, that zone will sustain higher parking rates than an industrial zone. Economic indicators are also considered to be an influential factor when establishing the parking rates. For example, because the socio-economic level in a particular zoning area indicates whether residents are able to pay a high or low parking rate, this should definitely be factored in when calculating the base parking rate for that zoning area. Similarly, accessibility and ease of use are also definite factors influencing the parking rate in a zoning area. Accessibility considers distance from the parking area to the destination; nearby parking is highly valued and the users would accordingly pay a higher rate than they would for less-favorable parking areas further from their destination. Ease of use and access should also consider available facilities within the parking area such as elevators, emergency ladders and visibility of signage which add value to the user and parking rates should be set accordingly. Therefore, the type and amenities associated with parking facilities should be considered when deciding on a fair and reasonable parking rate.

The earlier study by [5] analyzed the relationship between the general areas with parking spots reserved for motorcycles and the amount of time each of the spots were used by students on campus. These research results identified several variables that also influenced parking duration for members of the teaching faculty of UNS Surakarta 
including: differing lecture duration periods, organizations' activities, lecturers' assigned activities on campus, and other activities.

The purpose of this research is to: 1) determine criteria for each zone in the study area; 2) determine the weight and scoring for every zone using the AHP method; 3) analyze and determine the rates for parking with multiple criteria based on zoning. The ultimate goal of the study is to provide a beneficial tool for the Semarang city government to use in developing sustainable transportation plans.

\section{Research method}

This research method utilizes a field observation model along with questionnaires using one or more determined criterion in each zone, and then rate analysis is performed by prioritizing those criteria.

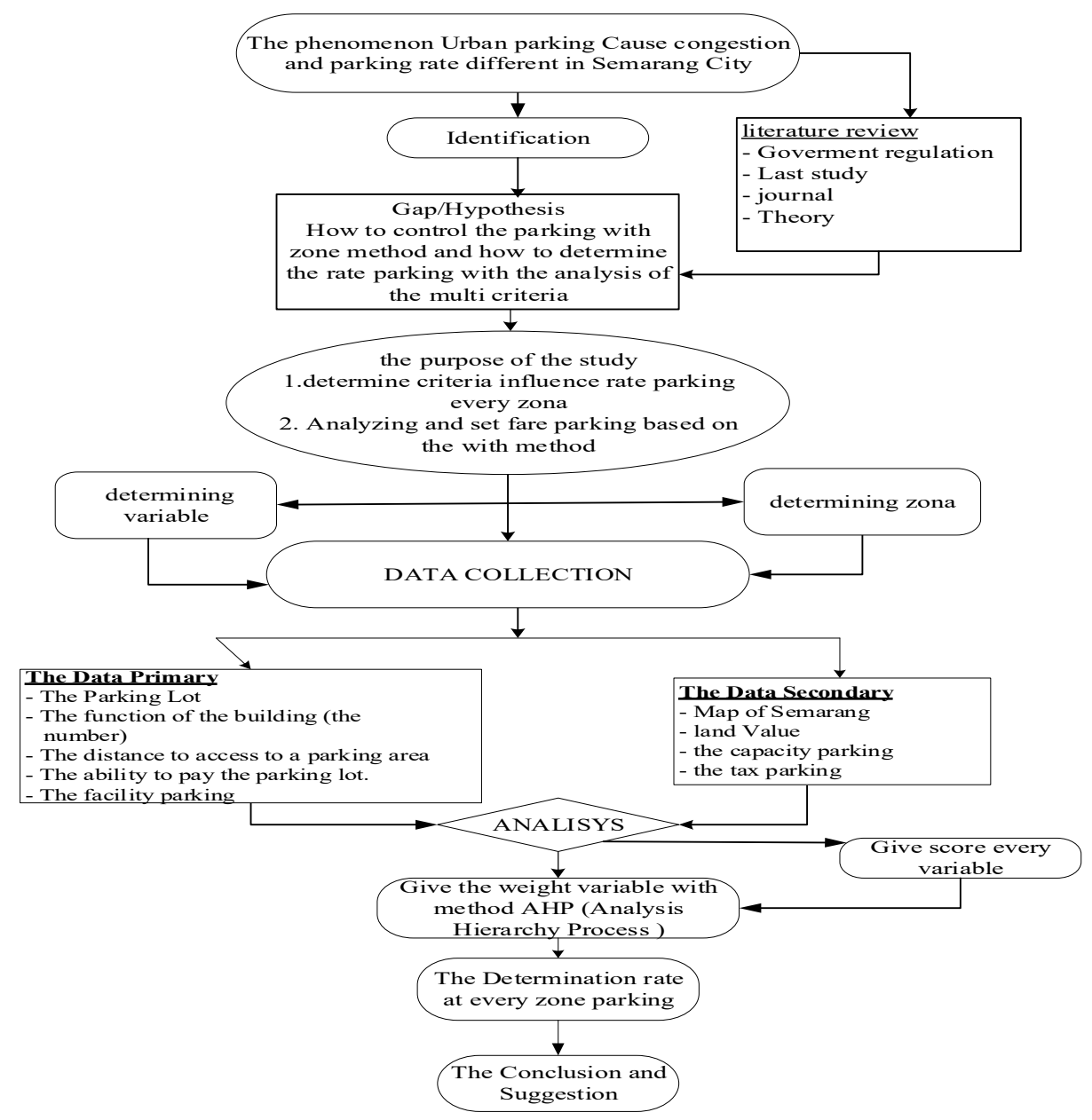

Fig. 1. Flow chart illustrating the research method

This analysis of rate determination based on zoning uses the Process Hierarchy (APH) method, starting with zoning determinations based on area use and area divisions that have already been established in the district regulations [14] governing Space Order Planning of the Semarang City Area. After setting basic definitions to identify the specific 
characteristics in Zone A, Zone B and Zone C, then the next step is to look at each zone individually, eventually assigning weight to each of the variables in its subset of criteria consistent with both the data from field observation results and with other related institution data (see Figure 1).

\section{Analysis and discussion}

\subsection{General description of study area}

Semarang, as a study area, has many characteristics that can be easily extrapolated for other urban areas. On a simplified, macro level: based on "Perda No 14 Tahun 2011" [14], the City of Semarang is divided into 10 sections. The Uptown area (BWK / Urban Boundaries), as a representational sample, is classified into 3 zones. Zone $\mathrm{A}$ is considered an expensive zone with land use primarily identified as trading/mercantile, offices, and business areas, and it covers the areas of BWK I, BWK II, BWK III and BWK V. Zone B is considered a middle zone with land use designated as industrial, and covers the areas of BWK IV, BWK IX and BWK X (BWK or Urban Boundaries). Zone C is considered an inexpensive zone with land uses including educational areas and military offices, and covers the areas of BWK VI, BWK VII and BWK VIII. These can be seen in Figure 2 and Table 1.

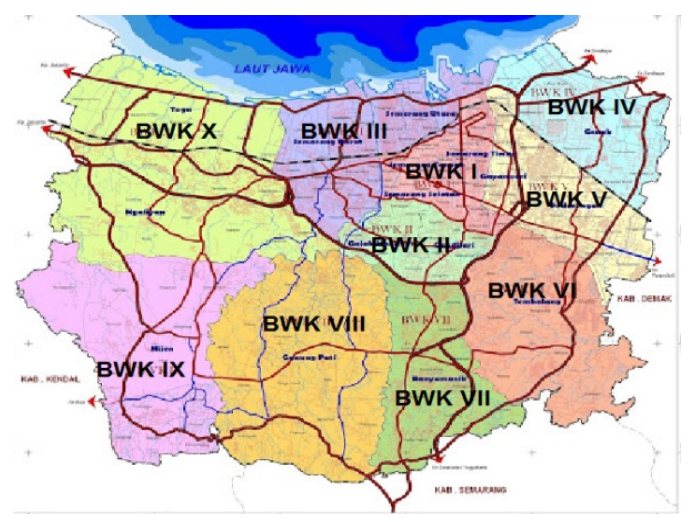

Fig. 2. Area classification of Semarang City based on BWK (BWK / Urban Boundaries). (Source: http://dppad.jatengprov.go.id)

Sampling was performed in one (1) BWK (Urban Boundaries) for each zone. Zone A sampling was represented by BWK I, Zone B by BWK IV and Zone C by BWK VI, as seen in Figure 2. 


\subsection{Analyzing the criteria within each zone}

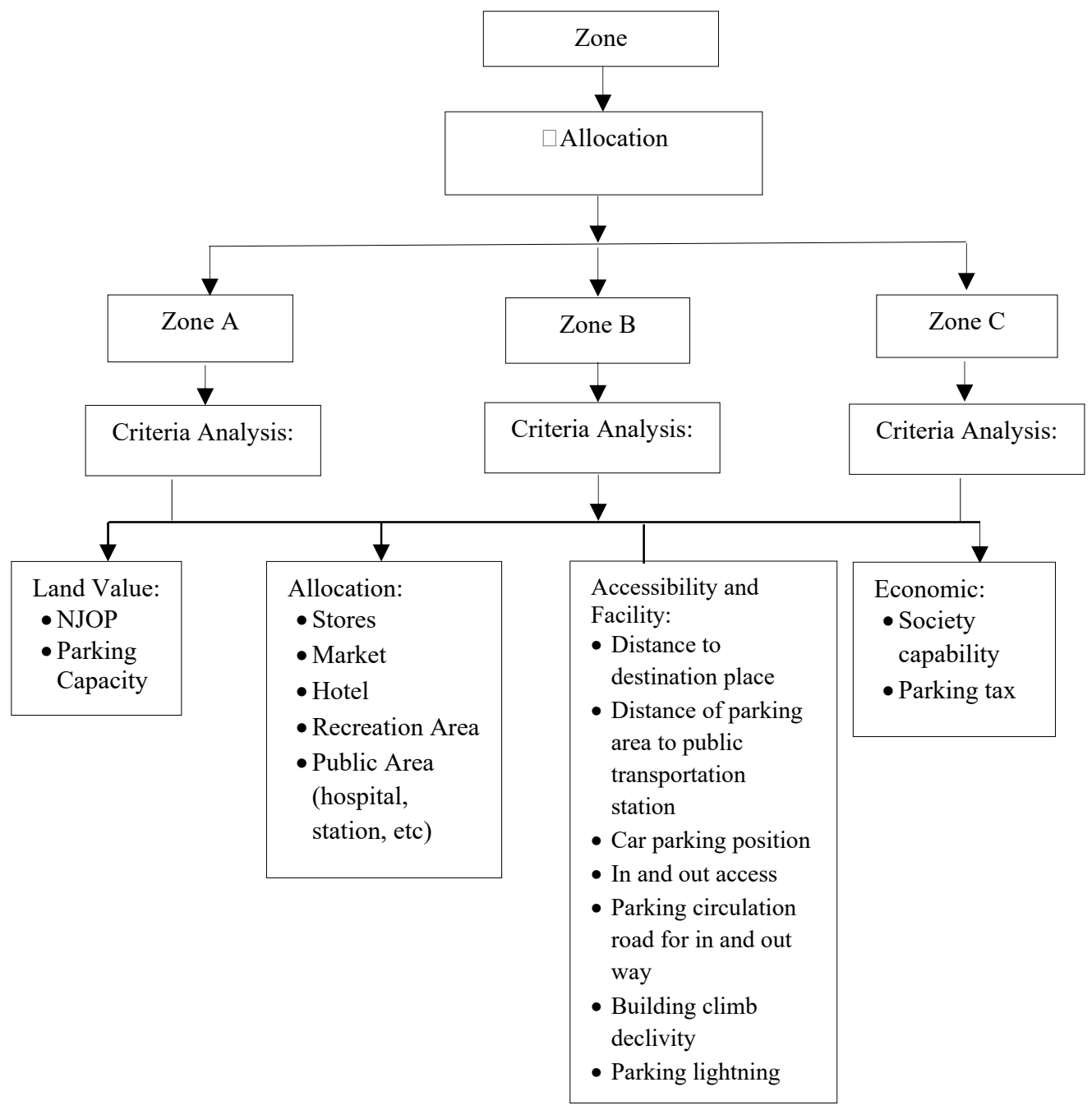

Fig. 3. Flow chart of criteria determination for each zone.

\subsection{Scoring determination}

The scoring determinations from data collection results by questionnaire and observations follow in Figure 4:

1. Zone A, considered an expensive zone with land use involving trade/mercantile services, offices, and business areas, consists of the areas of BWK I, BWK II, BWK III and BWK V (BWK = "Bagian Wilayah Kota" / Urban Boundaries).

2. Zone B, considered a middle zone with land use designated industrial, consists of the areas of BWK IV, BWK IX and BWK X (BWK = "Bagian Wilayah Kota" / Urban Boundaries).

3. Zone $\mathbf{C}$, considered an inexpensive zone with land uses including educational areas and military offices, consists of the areas of BWK VI, BWK VII and BWK VIII (BWK = "Bagian Wilayah Kota" / Urban Boundaries). 


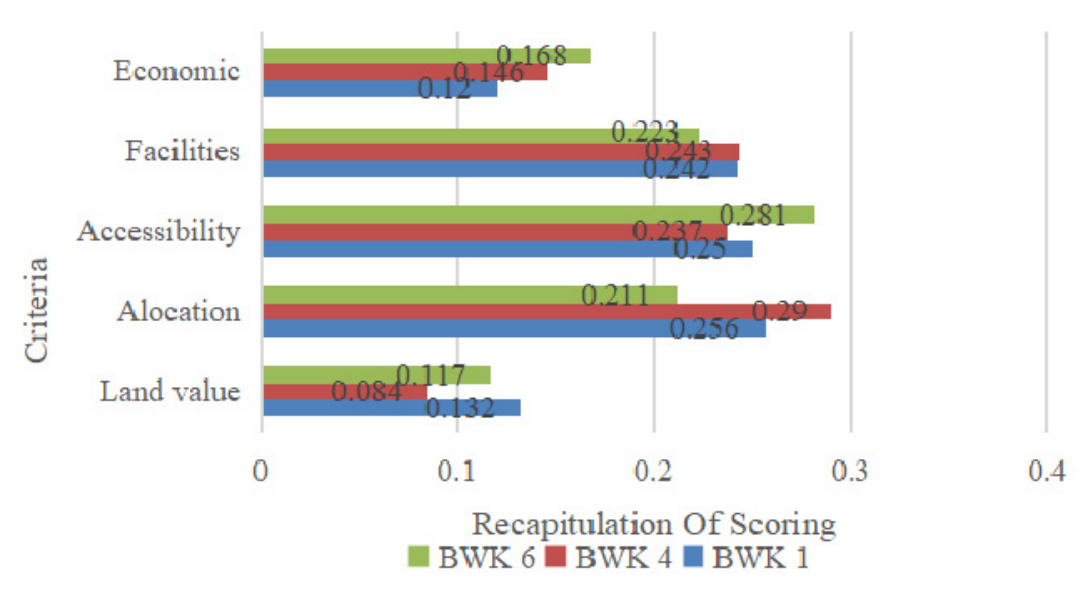

Fig. 4. Scoring results in Zone A, Zone B and Zone C.

\subsection{Analysis result of scoring}

The recapitulation of scoring results for each zone in BWK can be seen in Figure 4, and the results of land use valuing can be seen in Table 1. Value comparisons for each criterion in the representational sample BWK for each zone can be seen in Figure 3.

Table 1. Recapitulation of the valuing result for each criterion.

\begin{tabular}{|c|c|c|c|c|c|c|}
\hline \multirow{2}{*}{ No } & \multirow{2}{*}{ Land } & \multicolumn{5}{|c|}{ Weight } \\
\cline { 3 - 7 } & Function & K1 & K2 & K3 & K4 & K5 \\
\hline 1 & Trading & 0.132 & 0.256 & 0.25 & 0.242 & 0.12 \\
\hline 2 & Industrial & 0.084 & 0.289 & 0.237 & 0.24 & 0.147 \\
\hline 3 & Educational & 0.117 & 211 & 0.281 & 0.22 & 0.167 \\
\hline
\end{tabular}

Source: [10]

$\mathrm{K} 2=$ Criterion 2 is Allocation

$\mathrm{K} 3=$ Criterion 3 is Accessibility

$\mathrm{K} 4=$ Criterion 4 is Facility

$\mathrm{K} 5=$ Criterion 5 is Economic

Table 2. Recapitulation of scoring.

\begin{tabular}{|c|c|c|c|}
\hline \multirow{2}{*}{ Criteria } & \multicolumn{3}{|c|}{ Value } \\
\cline { 2 - 4 } & $\begin{array}{c}\text { BWK 1 } \\
\text { (Urban Boundaries) }\end{array}$ & $\begin{array}{c}\text { BWK 4 } \\
\text { (Urban Boundaries) }\end{array}$ & $\begin{array}{c}\text { BWK 6 } \\
\text { (Urban Boundaries) }\end{array}$ \\
\hline Land Value & 9 & 5 & 3 \\
\hline Allocation & 9 & 5 & 1 \\
\hline Accessibility & 7.667 & 3.67 & 1.667 \\
\hline Facility & 9 & 1 & 3 \\
\hline Economic & 9 & 5 & 1 \\
\hline
\end{tabular}

Source: [10]

After valuing and scoring for each criterion in every zone was determined, then those values were multiplied by the scoring to calculate the quality value for each zone. The quality value establishes the value of the parking rate for each zone by multiplying the comparison value with the base rate in every zone. The multiplied result of value and scoring is in Table 3. 
Table 3. Valuing analysis by scoring.

\begin{tabular}{|c|c|c|}
\hline \multicolumn{3}{|c|}{ Value } \\
\hline Zone A & Zone B & Zone C \\
\hline $\mathrm{K} 1=0.132 ; \mathrm{S}=9 ;$ & $\mathrm{K} 1=0.084 ; \mathrm{S}=5 ;$ & $\mathrm{K} 1=0.117 ; \mathrm{S}=3 ; \quad \mathrm{N}=0.35$ \\
\hline $\mathrm{K} 2=0.256 ; \mathrm{S}=9$ & $\mathrm{~K} 2=0.2895 ; \mathrm{S}=5 ; \quad \mathrm{N}=1.45$ & $\mathrm{~K} 2=0.211 ; \mathrm{S}=1 ; \quad \mathrm{N}=0.21$ \\
\hline $\mathrm{K} 3=0.25 ; \quad \mathrm{S}=7.66 ; \mathrm{N}=1.92$ & $\mathrm{~K} 3=0.2373 ; \mathrm{S}=3.67 ; \mathrm{N}=0.87$ & $\mathrm{~K} 3=0.281 ; \mathrm{S}=1.67 ; \mathrm{N}=0.47$ \\
\hline $\mathrm{K} 4=0.242 ; \mathrm{S}=9 ; \quad \mathrm{N}=2.18$ & $\mathrm{~K} 4=0.0 .243 ; \mathrm{S}=1 \quad ; \mathrm{N}=0.24$ & $\mathrm{~K} 4=0.223 ; \mathrm{S}=3 \quad ; \mathrm{N}=067$ \\
\hline $\mathrm{K} 5=0.12 ; \mathrm{S}=9 ; \quad \mathrm{N}=1.08$ & $\mathrm{~K} 5=0.1475 ; \mathrm{S}=5$ & $\mathrm{~K} 5=0.168 ; \mathrm{S}=1$ \\
\hline Total & 3.71 & 1.868 \\
\hline
\end{tabular}

Note:

$\mathrm{S}=$ Score of each criterion in every BWK

$\mathrm{N}=$ Final score of criteria after multiplied by the value of each criterion

The results of the scoring and valuing analysis can be seen in Table 3, indicating that Zone $\mathrm{A}$ has the highest value, followed by Zone $\mathrm{B}$ in the middle, and Zone $\mathrm{C}$ is the lowest, based on the criteria. When the final result of the scoring and valuing analysis is calculated, the total value of the three zones is equal to 14.23.

\subsection{Analysis result of parking rate determination}

The base parking rate is differentiated by zone. The rate determined for Zone A is based on the established criteria of an expensive rate zone, therefore the base value and any rate built upon it simply uses the parking rate already identified in the earlier research result. Parking in zones for trading/mercantile districts, offices and services areas is further divided into two sub-sections: first, a parking area in connection with a building/facility such as a store; and second, an area without a permanent building or facility, such as a traditional market. For parking areas connected with a building structure, the parking rate taken from the research of [2] is about Rp. 4,000.00/hour. The price for a parking rate in an area without a permanent building or structure, also taken from the research of [6], is about $\mathrm{Rp}$. $2,589.34$ /hour. This price was then multiplied by the BI rate of 4,75 percent, adjusting the rate in relation to the Indonesian economy as measured by indexes in July 2017 [2]. Parking rate prices after being multiplied by the BI Rate can be seen in Table 4 .

Table 4. Parking rate adjustments by year 2015-2017.

\begin{tabular}{|l|c|c|c|}
\hline \multirow{2}{*}{\multicolumn{1}{|c|}{ Location }} & \multicolumn{3}{|c|}{ Parking rate } \\
\cline { 2 - 4 } & $\mathbf{2 0 1 5}$ & $\mathbf{2 0 1 6}$ & $\mathbf{2 0 1 7}$ \\
\hline Mall of paragon & $\operatorname{Rp~4,000.00}$ & $\mathrm{Rp} 4,190.00$ & $\mathrm{Rp} 4,389.03$ \\
\hline Sampangan market & - & $\mathrm{Rp} 2,589.34$ & $\mathrm{Rp} 2,712.33$ \\
\hline
\end{tabular}

Source: $[2,6]$

Table 5. Shows the parking rates calculated for the first hour in BWK 1 (BWK or Urban Boundaries).

\begin{tabular}{|l|c|c|}
\hline \multirow{2}{*}{ Location } & \multicolumn{2}{|c|}{ Parking Rate } \\
\cline { 2 - 3 } & $\mathbf{2 0 1 7}$ & Absolute \\
\hline Trading Zone (Building) & Rp 4,389.03 & Rp 4,500.00 \\
\hline Trading Zone (Non-Building) & Rp 2,712.22 & Rp. 3,000.00 \\
\hline
\end{tabular}

Source: [10]

Determine the base parking rate; this is approximately $\mathrm{Rp} 2,000.00$. Zone $\mathrm{C}$, the inexpensive zone with lowest-value criteria, is based on Campus parking rates (Diponegoro University and POLINES). The parking rate price for cars at Diponegro University varies 
from approximately Rp. 1,000.00 to Rp. 3,000.00; at POLINES parking for cars is free. For these reasons, in BWK VI, the base parking rate has been set by using the highest existing parking rate, Rp.3,000.00. This is consistent and reasonable because a typical parking rate is difficult to establish since an average student is not permitted to bring a private vehicle onto campus. The base rates for each BWK can be seen in Table 6 . The base rates in each of the Zones, A, B, and C, are multiplied by 25 percent of the tax rate as determined from Semarang City District regulations no 10, year 2011 [14], and those rates are further adjusted for the next 10 years by 4,75 percent. These can be seen in Table 7 .

Table 6. Parking base rate analysis for each zone.

\begin{tabular}{|c|l|l|c|c|}
\hline \multirow{2}{*}{ Zone } & \multicolumn{2}{|c|}{ Land Function } & \multicolumn{2}{c|}{ Rate } \\
\cline { 3 - 5 } & \multicolumn{2}{|c|}{} & First hour & Next hour \\
\hline A & Tranding & Building & Rp 4,500.00 & Rp 2,250.00 \\
\cline { 3 - 5 } & & Non-building & Rp 3,000.00 & - \\
\hline B & Industrial & Rp 2,000.00 & - \\
\hline C & Educational & Rp 3,000.00 & - \\
\hline
\end{tabular}

Source: [10]

Table 7. Analysis of parking rate adjustments based on $25 \%$ of tax assessments and $4,75 \%$ interest rate.

\begin{tabular}{|c|c|c|c|c|}
\hline \multirow{2}{*}{ Zone } & \multicolumn{2}{|c|}{ Base rate } & 25 \% of Tax & $\begin{array}{l}\text { 4.75\% of } \\
\text { rate Interest }\end{array}$ \\
\hline \multirow{2}{*}{ Trading } & Building & $\operatorname{Rp~4,500.00~}$ & $\operatorname{Rp~5,625.00}$ & $\operatorname{Rp~8,946.66}$ \\
\cline { 2 - 5 } & Non - Building & $\operatorname{Rp~3,000.00}$ & $\operatorname{Rp~3,750.00}$ & $\operatorname{Rp~5,964.46}$ \\
\hline Industrial & & $\operatorname{Rp~2,000.00}$ & $\operatorname{Rp~2,500.00}$ & $\operatorname{Rp~3,976.31}$ \\
\hline Educational & Campus & $\operatorname{Rp~3,000.00}$ & $\operatorname{Rp~3,750.00}$ & $\operatorname{Rp~5,964.46}$ \\
\hline
\end{tabular}

Source: [10]

After the result of parking rate adjustments is determined (Table 7), it is then multiplied by the quality value (Table 3 ). In each zone this yields three (3) different parking rates

The formula for Zones B and C is calculated using the same method as Zone A. The calculated parking rates based on all quality values can be seen in Table 8 .

Table 8. Final analysis of parking rates using quality values for each zone.

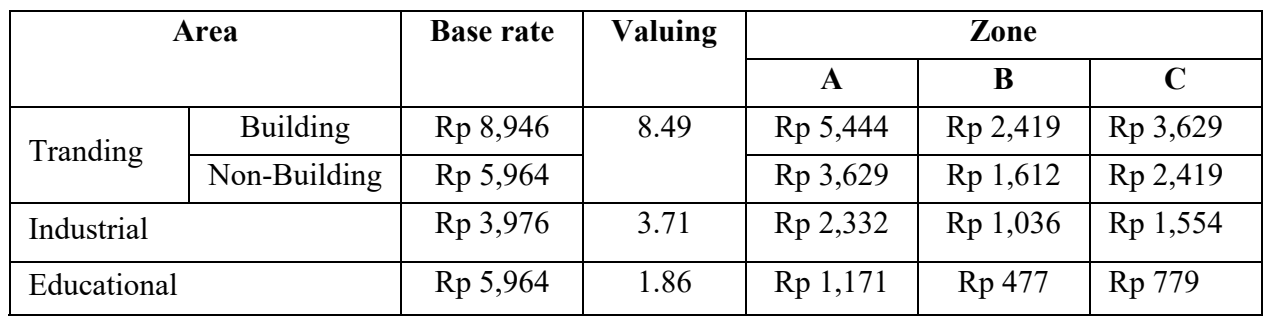

Using the calculated result of WTP [10], a minimum limit for parking rates can be established. If the rate price in Table 8 is lower than WTP, then the parking rate needs to be increased. Each zone will have differentiated parking rates for trade/mercantile operations within a building, trade conducted without a permanent structure (non-building), industrial, and educational areas.

Based on the research performed in CBD by [15], progressive parking rates can be established for the "next," or succeeding, hours by applying an incremental parking rate, set at $50 \%$ of the first-hour rate for trade/mercantile in-building/permanent structure areas. The 
rate for in-building trade, for purposes of this rate determination, is intended for department stores; shopping centers such as Super Indo or mini markets are not included. The rate for non-building trade/mercantile areas is intended to refer to traditional markets. The rate determination for educational areas is only valid for upper-level campus areas, not lower schools.

\section{Conclusion and recommendations}

\subsection{Conclusion}

Analysis of the results demonstrates that effective urban parking controls can be developed by basing parking rates by zone, using a multi-criterion analysis method, as follows:

A. The City of Semarang as a study city consisting of 10 BWK ("Bagian Wilayah Kota" / Urban Boundaries) is divided into 3 Zones: they are Zone A with the allocation for trading represented by BWK I, Zone B with the function for industrial represented by BWK IV and Zone $\mathrm{C}$ with the function for educational represented by BWK 6. By using multi-criterion method, it is found that factors influencing rate determination is created as criterion used in scoring and valuing analysis, they are land value, landused/allocation, accessibility, facility and economic. Each zone shows that they have different value. In Zone A and Zone B, the allocation criterion becomes the highest criterion, but in Zone $\mathrm{C}$, facility is the highest one. The different of this value influences the parking rate in each zone.

B. The formula which determines parking rates in each zone uses a coefficient calculated using value analysis, multiplied by scores established for each zone. The coefficient result for Zone $\mathrm{A}$ is equal to 8,49; for Zone $\mathrm{B}$ it equals 3,71; and in Zone $\mathrm{C}$ it is equal to 1,86 .

\subsection{Recommendations}

A. When setting parking rates based on zoning models in order to establish effective parking controls in urban areas, it is strongly recommended to use a comprehensive set of criteria, applying each criterion to all existing BWK zones in every urban area, which will enable the most accurate parking rates to be obtained.

B. For the most beneficial results, the preference would be to compare the parking rates derived from multi-criterion analysis with the residents' ATP (ability to pay) who live and work in the urban area being studied, since every urban center has different socioeconomic characteristics.

This research was financially supported by The Faculty of Engineering, Diponegoro University, Indonesia through Base Research Grant 2017.

\section{References}

1. A. Jayadi S. Universitas Muhammadiyah Surakarta, Indonesia (2014).

2. Andreas dan Grace. Tugas Akhir Universitas Diponegoro, Semarang. Indonesia (2015)

3. P. Barter, M.N. Prayudyanto, A. Jinca, GIZ-SUTIP, Palembang, 16 April 2012 (2012)

4. Direktorat Jendral Perhubungan Darat. Direktorat Jendral Perhubungan Darat. (1996)

5. F. Galandika, D. Handayani, M.H.M. Amirotul, Jurnal MATRIK TEKNIK SIPIL/Maret/135, UNS, Surakarta, Indonesia (2016) 
6. Gidion dan Dimas, Jurnal Karya siswa Universitas Diponegoro, Semarang, Indonesia (2016)

7. F. Hermawan., H. Indarto., I. Ismiyati, MATEC Web of Conferences 159, 01020 (2018); https://doi.org/10.1051/mateccnf/201815901020 (2018)

8. F.D. Hobbs, Universitas Gajah mada Press (ISBN:9794203564) (1995)

9. I.Ismiyati, Disertasi PDTAP Universitas Diponegoro, Semarang, Indonesia (2011)

10. I.Ismiyati,Wicaksono, YI dan Riyanto, B, Laporan Akhir Penelitian Dana Hibah Fakultas Teknik 2017, Universitas Diponegoro, Semarang, Indonesia (2017)

11. I.Ismiyati \& F.Hemawan, IOP Conf. Ser.: Earth Environ. Sci. 123012020 (2018)

12. Pemerintah Kota Semarang. Seketariat Daerah. Semarang, Indonesia (2012)

13. Pemerintah Kota Semarang, Seketariat Daerah. Semarang (2011)

14. Pemerintah Kota Semarang, Seketariat Daerah. Semarang (2011)

15. F. Prasetyo Ferdin, Universitas Jember, Indonesia (2013)

16. P. Rizki, I. Rajani, Universitas Diponegoro (2015)

17. L.Saaty, PT.Dharma Aksara Perkasa (1991)

18. Bappenas, GIZ, Indonesia (2015)

19. http://dppad.jatengprov.go.id) (diunduh, September, 2017: 23.00) 